\title{
Pembuatan Pestisida Nabati dan Pupuk Organik dari Kotoran Sapi Pada Kelompok Tani Kelurahan Klamalu Kabupaten Sorong
}

\author{
Akhmad Ali, ${ }^{1}$, Ponisri ${ }^{2 *}$, Adrianus Ogonei ${ }^{3}$, Febelina Sanggkek ${ }^{4}$ \\ 1,2,3 Universitas Muhammadiyah Sorong, Indonesia \\ *akhmad.ali1967@gmail.com
}

\begin{abstract}
ABSTRAK
Produk pertanian yang dilakukan oleh masyarakat selama ini masih menggunakan pestisida dan pupuk kimia sehingga hal ini tentunya akan sangat membahayakan bagi kesehatan, karena tanaman atau sayuran yang dikonsumsi tentunya masih mengandung bahan kimia. Untuk menggurangi penggunaan bahan-bahan kimia tersebut maka perlu adanya pestisida nabati dan penggunaan pupuk organik/kompos. Dimana pestisida nabati ini dapat dibuat yang bahan aktifnya berasal dari tanaman atau tumbuhan dan bahan organik lainya yang berkhasiat mengendalikan serangan hama pada tanaman. Pestisida ini tidak meninggalkan residu yang berbahaya pada tanaman maupun lingkungan serta dapat di buat dengan mudah menggunakan bahan yang murah dan peralatan yang sederhana. Sedangkan pupuk kompos ini dapat berasal dari bahan-bahan organik dan kotoran hewan yang bermanfaat untuk menyediakan unsur hara mikro bagi tanaman, mengemburkan tanah dan menyuburkan tanah-tanah tandus.
\end{abstract}

Kata kunci: Pestisida; Nabati; Kompos

\section{Making Vegetable Pesticides and Organic Fertilizers from Cow Manure in Farmers' Groups, Klamalu Village, Sorong Regency}

\begin{abstract}
Agricultural products made by the community so far still use pesticides and chemical fertilizers so this will certainly be very dangerous for health, because the plants or vegetables that are consumed of course still contain chemicals. To reduce the use of these chemicals, it is necessary to have vegetable pesticides and the use of organic fertilizers/compost. Where these vegetable pesticides can be made whose active ingredients come from plants or plants and other organic materials that are efficacious in controlling pest attacks on plants. This pesticide does not leave a residue that is harmful to plants or the environment and can be made easily using cheap materials and simple equipment. Meanwhile, this compost can come from organic materials and animal manure which are useful for providing micro-nutrients for plants, loosening the soil and fertilizing barren soils.
\end{abstract}

Keywords: Pesticide; Vegetable; Compost.

\section{PENDAHULUAN}

Produksi pertanian saat ini yang ditawarkan pada masyarakat, tanpa disadari terlalu tinggi bahan berbahaya yang terikutkan dalam produk, berakibat berbahaya yang mengancam dalam jangka panjang. Untuk itu, penting kesadaran stakeholder (pengambil kebijakan) mengantisipasi teknologi produksi dengan muatan lokal yang lebih akrab lingkungan dan menjamin kesehatan jangka panjang bagi masyarakat. Konsep pertanian ramah lingkungan adalah konsep pertanian yang mengedepankan keamanan seluruh komponen yang ada pada lingkungan ekosistem dimana pertanian ramah lingkungan mengutamakan tanaman maupun lingkungan serta dapat dilaksanakan dengan menggunakan bahan yang relatif murah dan peralatan yang relatif sederhana tanpa meninggalkan dampak yang negatif bagi lingkungan.

Pestisida Nabati adalah pestisida yang bahan aktifnya berasal dari tanaman atau tumbuhan dan bahan organik lainya yang berkhasiat mengendalikan serangan hama pada tanaman. Pestisida ini tidak meninggalkan residu yang berbahaya pada tanaman maupun 
lingkungan serta dapat di buat dengan mudah menggunakan bahan yang murah dan peralatan yang sederhana (Litbang, 2013).

Secara umum pestisida nabati diartikan sebagai suatu pestisida yang bahan dasarnya adalah tumbuhan. Pestisida nabati relatif mudah dibuat dengan bahan dan teknologi yang sederhana. Bahan bakunya yang alami/nabati membuat pestisida ini mudah terurai (biodegradable) di alam sehingga tidak mencemari lingkungan. Pestisida ini juga relatif aman bagi manusia dan ternak peliharaan karena residunya mudah hilang (Kardinan, 2002).

Sedangkan kompos merupakan salah satu jenis pupuk organik yang sudah ada sejak lama. Pengertian kompos adalah bahan-bahan organik yang sudah mengalami proses pelapukan karena terjadi interaksi antara mikroorganisme atau bakteri pembusuk yang bekerja di dalam bahan organik tersebut.

Penggunaan kompos sangat baik untuk tanah dan tanaman. Kompos dapat menyediakan unsur hara mikro bagi tanaman. Penggunaannya bisa sekaligus menggemburkan tanah yang tandus, meningkatkan porositas, aerasi, dan komposisi mikroorganisme di dalam tanah. Kompos juga berguna untuk meningkatkan daya ikat tanah terhadap air sehingga dapat menyimpan air tanah lebih lama. Ketersediaan air di dalam tanah dapat mencegah lapisan kering pada tanah. Penggunaan kompos bermanfaat untuk menjaga kesehatan akar serta membuat akar tanaman mudah tumbuh (Dinas Ketahanan Pangan, 2020).

\section{Permasalahan}

Pada masyarakat selama ini masih sangat kurang sekali penggunaan pestisida nabati dan penggunaan pupuk organik. Selama ini masyarakat lebih banyak menggunakan pestisida dan pupuk kimia atau anorganik. Hal ini karena pengetahuan dalam membuat pestisida nabati masih sangat kurang.

\section{Tujuan}

Untuk menambah pengetahuanmaupun wawasan masyarakat dalam pembuatan pestisida nabati dan cara pembuatan pupuk organik. Serta untuk dapat menggurangi penggunaan pestisida dan pupuk kimia sehingga sayuran atau tanaman yang dihasilkan tidak mengandung bahan kimia.

\section{METODE}

Pengabdian ini dilakukan pada kelompok tani Tunas Harapan II Kelurahan Klamalu Kabupaten Sorong. Metode yang digunakan dalam pelaksanaan pengabdian ini menggunakan beberapa pendekatan yaitu:

1. Penyuluhan Partisipatif yaitu kegiatan yang dilakukan dengan masyarakat yang berpartisipasi secara intaeraktif, dimana kegiatan ini menyangkut pembelajaran tentang pembuatan pestisida nabati dan cara membuat kompos dari kotoran sapi.

2. Focus group discussion (FGD) ditujukan untuk memecahkan suatu masalah untuk mencapai tujuan tertentu dalam suatu kelompok masyarakat, dengan mengindentifikasi masalahmasalah yang menghambat hasil budidaya tanaman.

3. Pelatihan dilakukan dalam upaya pengembangan cara pembuatan pestisida nabati dan pembuatan pupuk kompos dari kotran sapi.

\section{HASIL DAN PEMBAHASAN}

\section{A. Pembuatan Pestisida Nabati untuk Mengendalikan Kutu Aphis}

Alat dan Bahan:

Alat : Blender

$$
\text { Baskom/Loyang }
$$

Bahan : 30 Lembar daun sirsak

5 siung bawang putih

1 liter air 
Cara membuat:

Pembuatan Pestisida Nabati pertama siapkan daun sirsak 30 lembar, bawang putih 5 siung lalu ditumbuk/diblender hingga merata lalu campurkan air 1 liter diamkan selama 1 malam baru bisa diaplikasikan ketanaman dengan perbandingan 1 larutan Nabati dicampur dengan 1 liter air, untuk mengendalikan kutu aphis pada tanaman sayuran.

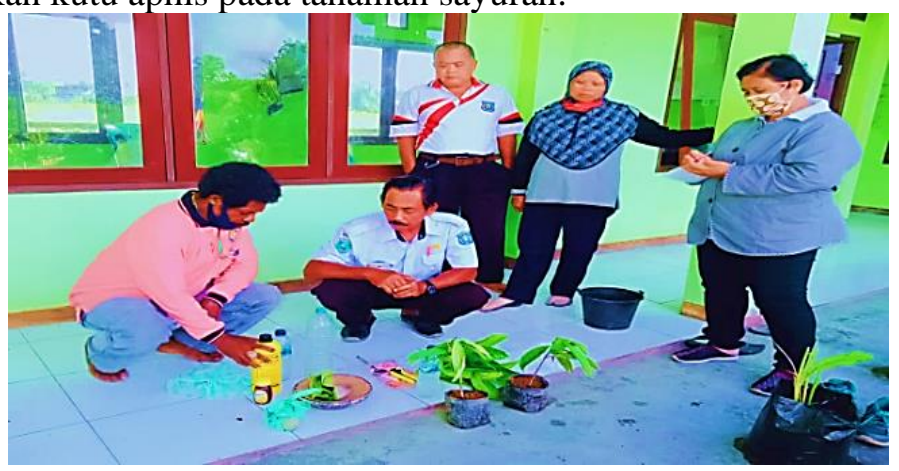

Gambar 1. Cara Membuat Pestisida Nabati

\section{B. Pembuatan Pupuk Kompos Organik.}

Alat dan Bahan:

Alat : Sekop

Cangkul

Terpal

Bahan : $100 \mathrm{~kg}$ kotoran sapi

$10 \mathrm{~kg}$ dedak/bekatul

EM-4 1 gelas aqua

2 sendok gula pasir

20 liter air

Cara membuat:

Pembuatan pupuk kompos yang harus disiapkan kotoran sapi $100 \mathrm{~kg}$, dedak/bekatul $10 \mathrm{~kg}$, EM41 gelas aqua, gula pasir 2 sendok cara kerja kotoran sapi di taruh di terpal lalu ratakan taburkan dedak diatas kotoran sapi kemudian siapkan air 1 ember/ 20 liter masukkan EM-4 dan gula kedalam air tersebut aduk hingga rata lalu siramkan kemedia kotoran sapi dan dedak sambil diaduk - aduk sampai merata dan lembab baru tutup adonan tersebut selama 7 hari akan tetapi setiap 2 hari sekali dibuka dan diaduk kembali baru tutup kembali setelah 7 hari baru baru pupuk tersebut jadi dan di dingginkan selajutnya masukkan pupuknya kedalam karung maka pupuk siap digunakan.

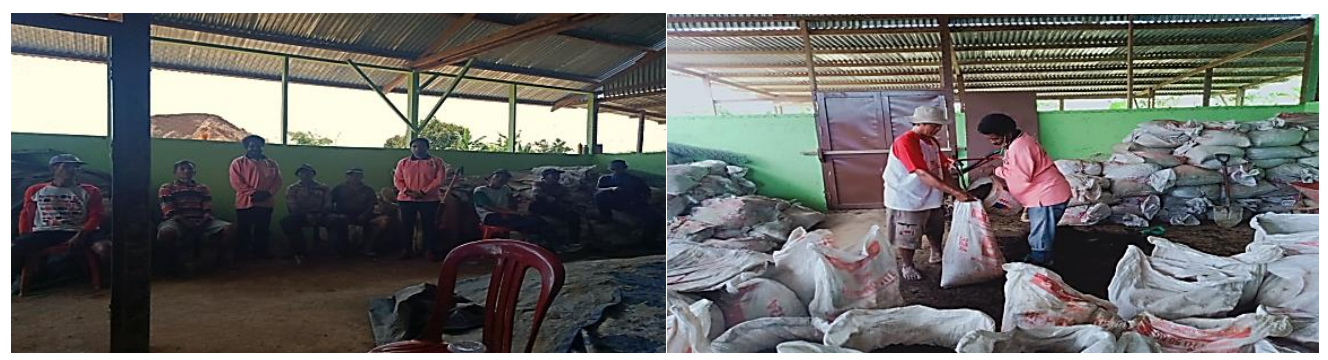

Gambar 2. Pembuatan dan Pengepakan Pupuk Kompos

\section{SIMPULAN}

Penggunaan pestisida nabati dan pupuk kompos lebih aman dibandingkan dengan bahan kimia, dan cara pembuatannya juga lebih mudah dan serderhana. 


\section{DAFTAR PUSTAKA}

Kardinan A, 2002 . Pestisida Nabati Ramuan dan Aplikasi. Penebar Swadaya. Jakarta.

Litbang. 2013. Balai Pengkajian Teknologi Pertanian Sulawesi Utara

Dinas Ketahanan Pangan. 2020. https://www.pertanianku.com/pengertian-kompos-dankegunaannya-untuk-kesuburan-tanah/ Buleleng. 